\title{
KECERNAAN SERAT KASAR DAN PROTEIN KASAR RANSUM YANG MENGANDUNG PELEPAH DAUN KELAPA SAWIT DENGAN PERLAKUAN FISIK, BIOLOGIS, KIMIA DAN KOMBINASINYA PADA DOMBA
}

\section{Digestibility of Crude Fiber and Crude Protein Diet Containing Oil Palm Frond Treated by Physical, Biological and Chemical on Sheep}

\author{
Edidis Periasantana Gultom ${ }^{1}$, Tri Hesti Wahyuni ${ }^{2}$ dan Ma'ruf Tafsin ${ }^{2}$ \\ 1. Mahasiswa Program Studi Peternakan Fakultas Pertanian Universitas Sumatera Utara' \\ 2. Staf Pengajar Program Studi Peternakan Fakultas Pertanian Universitas Sumatera Utara
}

\begin{abstract}
Oil palm frond need treatments to increase nutritional. Value for diet this study aims to analyze the digestibility of crude fiber and crude protein diet containing oil palm frond treated by physical, chemical, biological and combination on sheep. This research was conducted at the Laboratory of Anymal Biology, Departement of Animal Husbandry, Faculty of Agriculture, University of Sumatera Utara, from june to august 2013. This research used a completely randomized design (CRD) with four treatments and four replications, using 16 local sheep with an average initial body weight of $10 \pm 1,16 \mathrm{~kg}$. The treatments consist oil palm frond by physical (P0), biological $(P 1)$, chemical (P2) and combination (P3). Variables were measured consist of consumption crude fiber and crude protein, digestibility of crude fiber and crude protein. The results showed that the consumption of crude fiber (g/head/day) in physical and biological (78.94 and 79.98) was significantly higher than chemical and combination (66.93 and 59.92), while consumption of crude protein (g/head/ekor) in biological (59.45) was significantly higher than physical, chemical and combination (39.21, 39.86 and 45.13). Digestibility of crude fiber (\%) in combination (68.97) was significantly higher than physical, biological and chemical (50.29, 64.38 and 59.93), while digestibility of crude protein (\%) in biological, chemical and combination (79.97, 79.32 and 81.03) was significantly higher than physical (71.31). Conclusion of this research was the oil palm frond treated by combination of physical, biological and chemical increase digestibility of crude fiber and crude protein in sheep.
\end{abstract}

Keywords: Oil Palm Frond; Physical; Chemical; Biological; Combination, Consumption and Digestibility.

\begin{abstract}
ABSTRAK
Pelepah daun kelapa sawit diperlukan perlakuan untuk meningkatkan kandungan nutrisinya. Penelitian ini bertujuan untuk menguji pemanfaatan ransum yang mengandung pelepah daun kelapa sawit dengan perlakuan fisik, biologi, kimiawi dan kombinasinya terhadap kecernaan serat kasar dan protein kasar. Penelitan ini dilaksanakan di Laboratorium Biologi Ternak, Departemen Peternakan, Fakultas Pertanian, Universitas Sumatera Utara, Medan yang dilaksanakan pada bulan Juni-Agustus 2013. Penelitian ini menggunakan rancangan acak lengkap (RAL) dengan empat perlakuan dan empat ulangan, menggunakan domba lokal jantan sebanyak 16 ekor dengan rataan bobot badan awal $10 \pm 1,16 \mathrm{~kg}$. Perlakuan yang diuji terdiri atas pelepah daun kelapa sawit dengan perlakuan fisik (P0); biologi (P1); kimia (P2) dan kombinasi (P3). Parameter yang diamati adalah konsumsi serat kasar dan konsumsi protein kasar, kecernaan serat kasar dan kecernaan protein kasar. Hasil penelitian menunjukkan bahwa konsumsi serat kasar (g/ekor/hari) pada perlakuan fisik dan biologi (78.94 dan 79.98) nyata lebih tinggi dibanding perlakuan kimia dan kombinasi (66.93 dan 59.92), konsumsi protein kasar (g/ekor/hari) pada perlakuan biologi $(59,45)$ nyata lebih tinggi disbanding perlakuan fisik, kimia dan kombinasi $(39.21,39.86$ dan 45,13). Kecernaan serat kasar (\%) pada perlakuan kombinasi (68.97) nyata lebih tinggi disbanding perlakuan fisik, biologi dan kimia $(50.29,64.38$ dan 59.93), kecernaan protein kasar (\%)pada perlakuan biologi, kimia dan kombinasi $(79.97,79.32$ dan 81.03) nyata lebih tinggi dibanding perlakuan fisik (71.31). Kesimpulan hasil penelitian ini adalah pemberian ransum yang mengandung pelepah daun kelapa sawit dengan perlakuan kombinasi dari perlakuan fisik, biologi dan kimia meningkatkan kecernaan serat kasar dan kecernaan protein kasar pada domba.
\end{abstract}

Kata kunci: Pelepah Daun Kelapa Sawit; Fisik; Biologis; Kimia; Kombinasinya, Konsumsi dan Kecernaan. 


\section{PENDAHULUAN}

Peternakan merupakan sektor penyumbang terbesar dalam penyediaan kebutuhan pangan khususnya kebutuhan protein hewani. Kebutuhan protein hewani semakin meningkat seiring dengan pertambahan penduduk, meningkatnya pengetahuan, peningkatan pendapatan serta kesadaran akan pentingnya kebutuhan protein dalam kehidupan manusia. Domba memberikan peranan besar dalam memproduksi bahan makanan protein hewani yang dibutuhkan untuk peningkatan mutu sumber daya manusia.

Usaha peternakan di Indonesia merupakan peternakan rakyat dengan ciri-ciri: skala usahanya masih relatif kecil, motif usaha produksi rumah tangga, dilakukan sebagai usaha sampingan, menggunakan teknologi sederhana sehingga produktivitasnya rendah dan mutu produksinya bervariasi. Salah satu cara untuk mengatasinya adalah dengan memperbaiki kualitas pakan, namun pakan komersial yang berkualitas relatif mahal, dimana penggunaan pakan komersial tidak selalu menjamin penambahan pendapatan dalam usaha pembesaran atau penggemukan domba.

Mengatasi permasalahan tersebut, harus diupayakan untuk mencari pakan alternatif yang potensial, murah dan mudah diperoleh serta tersedia sepanjang tahun. Pelepah daun kelapa sawit merupakan salah satu limbah perkebunan kelapa sawit, dimana keberadaannya cukup tersedia melimpah sepanjang tahun di Indonesia khususnya sumatera utara.

Kendala utama dalam pemanfaatan pelepah daun kelapa sawit sebagai pakan ternak adalah kandungan serat kasarnya yang tinggi dan protein serta kecernaan yang rendah.Pelepah daun kelapa sawit memiliki nilai kecernaan yang rendah terhadap ternak, hal ini dikarenakan kandungan lignin yang terdapat pada pelepah daun kelapa sawit.

Penggunaan pelepah daun kelapa sawit sebagai pakan tunggal tidak dapat memenuhi kebutuhan nutrisi yang dibutuhkan oleh domba. Untuk meningkatkan nilai nutrisi dari pelepah daun kelapa sawit dapat dilakukan dengan melakukan pengolahan baik fisik, biologi, kimia dan kombinasinya

Berdasarkan uraian di atas maka perlu dilakukan penelitian untuk mengetahui sejauh mana pengaruh pemberian limbah perkebunan tersebut yang mempunyai kandungan nutrisi rendah sehingga diharapkan dengan pengolahan secara fisik, kimia, biologis dan kombinasi menjadikan pakan yang lebih bermutu sehingga dapat bermanfaat untuk meningkatkan kecernaan dan memenuhi kebutuhan gizi ternak ruminansia. 


\title{
BAHAN DAN METODE PENELITIAN
}

\section{Tempat dan Waktu Penelitian}

Penelitian dilaksanakan di Laboratorium Biologi Ternak, Program Studi Peternakan, Fakultas Pertanian, Universitas Sumatera Utara, Medan.Penelitian berlangsung selama 3 bulan dimulai bulan Juni 2013 sampai Agustu 2013.

\section{Bahan dan Alat Penelitian}

\section{Bahan}

Ternak yang digunakan dalam penelitian ini adalah domba lokal jantan lepas sapih sebanyak 16 ekor dengan rataan bobot badan $10 \pm 1.16 \mathrm{~kg}$,pakan konsentrat yang terdiri atas bungkil inti sawit, dedak padi, molasses, urea, mineral mix dan garam. Pelepah daun kelapa sawit fermentasi sebagai pengganti pakan rumput ternak, Aspergillus niger sebagai fermentor pelepah kelapa sawit, Urea untuk mengamoniasi pelepah daun kelapa sawit obat-obatan seperti obat cacing (kalbazen), anti bloat untuk obat gembung, Rhodallon untuk desinfektan dan vitamin. Air minum diberikan secara ad libitium.

\begin{abstract}
Alat
Kandang terdiri atas kandang individu 20 unit dengan ukuran 1 x $1 \mathrm{~m} 2$ beserta perlengkapannya, ember sebanyak 20 buah tempat pakan dan 20 buah tempat minum, timbangan untuk menimbang bobot hidup berkapasitas $150 \mathrm{~kg}$ dengan kepekaan $50 \mathrm{~g}$, timbangan berkapasitas $2 \mathrm{~kg}$ dengan kepekaan $10 \mathrm{~g}$ untuk menimbang pakan, terpal plastik untuk menjemur bahan pakan, alat penerangan, goni plastik, alat tulis.
\end{abstract}

\section{Metode Penelitian}

Rancangan percobaan yang digunakan dalam penelitian ini adalah secara experimental dengan menggunakan rancangan acak lengkap (RAL) dengan 4 perlakuan dan 4 ulangan. Adapun perlakuan tersebut sebagai berikut:

P0: Pelepah daun kelapa sawit diolah secara fisik (chooper)

P1: Pelepah daun kelapa sawit diolah secara kimia (fisik +urea)

P2: Pelepah daun kelapa sawit diolah secarabiologis (fisik + Aspergillus niger)

P3: Kombinasi pengolahan pelepah daun kelapa sawit (fisik, kimia dan biologis) 


\section{Parameter Penelitian}

\section{a. Konsumsi serat kasar dan protein kasar}

Konsumsi serat kasar dan protein kasar diukur dengan mengalikan konsumsi ransum dengan kandungan serat kasar dan protein kasar yang diperoleh dari data analisis di laboratorium (Tillman et al., 1991). Periode pengukuran dilakukan selama satu minggu.

\section{b. Kecernaan Serat Kasar (KcSK)}

Kecernaan serat kasar dapat diukur dengan menghitung berdasarkan rumus:

$K c S k=\underline{(S K \text { Konsumsi }- \text { SK dari feses })} \times 100 \%$

$$
\text { SK konsumsi }
$$

(Siregar, 2009)

Konsumsi dan pengeluaran feses (SK) diperoleh dalam jangka waktu pengukuran selama periode koleksi yaitu satu minggu.

\section{c. Kecernaan Protein Kasar (KcPK)}

Kecernaan protein kasar dapat diukur dengan menghitung berdasarkan rumus:

$K c P K=(P K$ Konsumsi $-P K$ darifeses $) \times 100 \%$

PK Konsumsi

(Siregar, 2009)

Konsumsi dan pengeluaran feses (PK) diperoleh dalam jangka waktu pengukuran selama periode koleksi yaitu selama satu minggu.

\section{HASIL DAN PEMBAHASAN}

\section{Konsumsi Serat Kasar}

Nilai rataan konsumsi serat kasar tertinggi pada perlakuan P1 yaitu $79.98 \pm 2.22$ g/ekor/hari dan terendah pada perlakuan P3 yaitu sebesar 59.92 \pm 10.51 g/ekor/hari. Berdasarkan analisis ragam bahwa pemberian ransum yang mengandung pelepah daun kelapa sawit yang 
diolah dengan perlakuan fisik, biologi, kimia dan kombinasinya memberi pengaruh sangat nyata $(\mathrm{P}<0.01)$ terhadap konsumsi serat kasar.

Hasil uji lanjut BNT menunjukkan bahwa perlakuan P0 dan P1 memberi pengaruh yang sama terhadap konsumsi serat kasar tetapi berbeda kepada perlakuan P2 dan P3 yang lebih rendah konsumsinya, Hal ini disebabkan oleh pelepah daun kelapa sawit yang diolah secara biologi (fermentasi) dapat mengubah struktur fisik bahan yang kasar dan menurunkan kandungan serat kasar karena adanya pemecahan kandungan lignin dari pelepah daun kelapa sawit sehingga kandungan nutrisi meningkat, fermentasi juga memberi pengaruh terhadap kenampakan pakan dan bau yang lebih disukai ternak sehingga meningkatkan selera ternak dalam mengkonsumsi pakan.

Tabel 1. Rekapitulasi hasil penelitian

\begin{tabular}{ccccc}
\hline Perlakuan & $\begin{array}{c}\text { Konsumsi SK } \\
\text { (g/ekor/hari) }\end{array}$ & $\begin{array}{c}\text { Konsumsi PK } \\
\text { (g/ekor/hari) }\end{array}$ & $\begin{array}{c}\text { Kecernaan SK } \\
(\%)\end{array}$ & $\begin{array}{c}\text { Kecernaan } \\
\text { PK }(\%)\end{array}$ \\
\hline P0 & $78.94 \pm 4.99^{\mathrm{A}}$ & $39.21 \pm 2.48^{\mathrm{B}}$ & $50.29 \pm 3,8^{\mathrm{c}}$ & $71.31 \pm 2.3^{\mathrm{B}}$ \\
P1 & $79.98 \pm 2.22^{\mathrm{A}}$ & $59.45 \pm 1.65^{\mathrm{A}}$ & $64.38 \pm 3,1^{\mathrm{b}}$ & $79.97 \pm 2.1^{\mathrm{A}}$ \\
P2 & $66.93 \pm 4.45^{\mathrm{B}}$ & $39.86 \pm 2.65^{\mathrm{B}}$ & $59.93 \pm 2,2^{\mathrm{b}}$ & $79.32 \pm 1.1^{\mathrm{A}}$ \\
P3 & $59.92 \pm 10.51^{\mathrm{B}}$ & $45.13 \pm 7.92^{\mathrm{B}}$ & $68.97 \pm 2,2^{\mathrm{a}}$ & $81.03 \pm 1.3^{\mathrm{A}}$
\end{tabular}

Ket $\overline{\mathrm{AB} \text { : Superskrip yang berbeda pada kolom yang sama menunjukkan perbedaan yang sangat nyata }(\mathrm{P}<0.01)}$ $\mathrm{Abc}$ :Superscrip yang berbeda pada kolom yang sama menunjukkan perberbedaan yang nyata $(\mathrm{P}<0.05)$

Aplikasi perlakuan secara biologi dalam pengolahan bahan pakan limbah bertujuan untuk megubah struktur fisik bahan, pengawetan dan meningkatkan kandungan nutrisi bahan Muchtadi et al., (1992). Pada perlakuan kimia (amoniasi) dan kombinasi aromanya menyegat dan kurang disukai ternak hal ini sesuai dengan pernyataan Thomaszewska., et al (1993) yang menyatakan bahwa tingkat konsumsi sangat dipengaruhi oleh koefisien cerna, kualitas pakan, fermentasi dalam rumen serta status fisiologi ternak.

\section{Konsumsi Protein Kasar}

Nilai rataan konsumsi protein kasar tertinggi pada perlakuan P1 yaitu $59.45 \pm 1.65 \mathrm{~g} / \mathrm{ekor} / \mathrm{hari}$ dan terendah pada perlakuan P0 yaitu sebesar $39.21 \pm 2.48 \mathrm{~g} /$ ekor/hari. 
Hasil analisis ragam menunjukkan bahwa konsumsi protein kasar berpengaruh sangat nyata $(\mathrm{P}<0.01)$ terhadap protein kasar.

Hasil uji lanjut BNT menunjukkan bahwa perlakuan P0, P2 dan P3 memberi pengaruh yang sama terhadap konsumsi protein kasar tetapi berbeda dengan perlakuan P1. Perlakuan P1 konsumsi protein kasar lebih tinggi disebabkan perlakuan fermentasi dengan Aspergillus niger dapat mengubah struktur fisik bahan, dan meningkatkan kandungan nutrisi bahan.

Fermentasi dapat mengubah aroma, rasa dan tekstur bahan dan lebih disukai ternak yang menyebabkan jumlah atau tingkat konsumsi tenak terhadap protein kasar meningkat. Hal ini sesuai dengan pernyataan Kartadisastra (1997) keadaan fisik dan kimiawi ditunjukkan oleh bau, kenampakan rasa dan tekstur yang menumbuhkan daya tarik dan merangsang ternak untuk mengkonsumsinya.

Aplikasi perlakuan secara biologi dalam pengolahan bahan pakan limbah bertujuan untuk mengubah struktur fisik bahan, pengawetan dan meningkatkan kandungan nutrisi, proses fermentasi dapat dikatakan sebagai proses "protein enrichment” yang berarti proses pengkayaan protein dalam bahan dengan menggunakan mikroorganisme tertentu (sarwono, 1996).

\section{Kecernaan Serat Kasar}

Nilai rataan kecernaan serat kasar tertinggi pada perlakuan P3 yaitu $68.97 \pm 2,2 \%$ dan terendah pada perlakuan P0 yaitu sebesar 50.29 $\pm 3,8 \%$. Hasil analisis ragam menunjukkan bahwa pemberian ransum yang mengandung pelepah daun kelapa sawit dengan perlakuan fisik, biologi, kimia dan kombinasi berpengaruh nyata $(\mathrm{P}<0.05)$ terhadap kecernaan serat kasar.

Hasil uji lanjut BNT menunjukkan bahwa perlakuan P1 dan P2 memeri pengaruh yang sama tetapi berbeda terhadap perlakuan P0 dan P3. Kecernaan serat kasar tertinggi terdapat pada perlakuan kombinasi (P3) sebesar 68.97\% yang diikuti berturut-turut oleh perlakuan biologi (P1) dan perlakuan kimia (P2), terlihat pada P1 dan P2 tidak berbeda nyata, sedangkan yang tertinggi terdapat pada perlakuan kombinasi (P3).

Hal ini disebabkan oleh pelepah daun kelapa sawit yang diolah dengan cara kombinasi dari fisik, biologi dan kimia serat kasarnya cenderung berkurang karena pelepah daun kelapa sawit mengandung lignin dengan gugus karbohidrat yang menyebabkan kandungan serat kasarnya tinggi, proses kombinasi dapat menurunkan serat kasar karena urea yang terkandung pada proses kombinasi menghasilkan urease oleh mikroba pakan yang akan merubah lignin 
menjadi amoniak dan karbondioksida, adanya pelepasan ikatan karbondioksida mengakibatkan turunnya kandungan serat kasar pada pelepah daun kelapa sawit. kandungan serat kasar pakan yang rendah mengakibatkan kecernaan serat kasar meningkat karena kandungan serat kasar mempunyai hubungan yang negatif terhadap kecernaan. Hal ini sesuai dengan pernyataan Despal (2000) kandungan serat kasar memiliki hubungan yang negatif dengan kecernaan. Semakin rendah serat kasar maka semakin tinggi kecernaan ransum. Tillman et al., (1991) menyatakan bahwa Serat kasar mempunyai pengaruh terbesar terhadap daya cerna. Selulosa dan hemiselulosa yang sukar dicerna terutama bila mengandung lignin.

Kecernaan yang paling baik terdapat pada perlakuan P3 (pelepah daun kelapa sawit yang diolah secara kombinasi), hal ini disebabkan oleh kandungan serat kasar pada perlakuan P3 lebih rendah. Mcdonald et al., (2002) menyatakan bahwa serat kasar yang terkandung pada pakan tiap perlakuan sangat penting pengaruhnya terhadap daya cerna serat kasar ternak terhadap pakan tersebut.

Kecernaan pakan didefenisikan dengan cara menghitung bagian zat makanan yang tidak dikeluarkan melalui feses dengan asumsi zat makanan tersebut telah diserap oleh ternak, biasanya dinyatakan berdasarkan bahan kering dan sebagai suatu koefisien atau persentase. Selisih antara nutrient yang dikandung dalam bahan pakan dengan nutiren yang ada dalam feses merupakan bagian nutrient yang dicerna.

\section{Kecernaan Protein Kasar}

Nilai rataan kecernaan protein kasar tertinggi pada perlakuan P3 yaitu $81.03 \pm 1.3 \%$ dan terendah pada perlakuan P0 yaitu sebesar $71.31 \pm 2.3 \%$. Perbedaan nilai rataan kecernaan protein kasar akan berpengaruh terhadap produksi ternak. Hal ini sesuai dengan pernyataan Van Soest (1994) yang menyatakan bahwa rendahnya tingkat produktivitas ternak antara lain disebabkan rendahnya kualitas bahan pakan. Rendahnya nilai nutrisi bahan pakan tersebut ditunjukkan dengan rendahnya nilai protein, tingginya kandungan serat kasar dan rendahnya nilai biologis bahan makanan tersebut.

Hasil analisis ragam menunjukkan bahwa pemberian pakan pelepah daun kelapa sawit berpengaruh sangat nyata $(\mathrm{P}<0.01)$ terhadap kecernaan protein kasar. Hasil uji lanjut $\mathrm{BNT}$ menunjukkan bahwa perlakuan P1, P2 dan P3 sama pengaruhnya terhadap kecernaan protein 
kasar tetapi berbeda terhadap perlakuan P0. Perlakuan P3 memiliki kecernaan protein kasar lebih tinggi.

Hal ini disebabkan perlakuan kombinasi dari fisik, biologi dan fisik terhadap pelepah daun kelapa sawit dapat meningkatkan kandungan protein kasar pakan, meningkatnya kandungan protein kasar pakan disebabkan adanya penambahan urea (amoniasi) pada pelepah daun kelapa sawit yang dapat merangsang pertumbuhan moikroorganisme dan adanya penguraian kandungan lignin dalam pelepah sawit menjadi ammonia dan karbondioksida yang selanjutnya digunakan untuk pembentukan asam amino untuk pembentukan kandungan potein kasar sehingga kecernaan protein kasarnya meningkat.

Hal ini sesuai dengan pernyataan Boorman (1980) yang menyatakan bahwa proses pemanfaatan protein salah satunya dipengaruhi oleh jumlah protein yang dikonsumsi. Konsumsi protein dipengaruhi oleh level pemberian pakan. Pemberian pakan yang tidak dibatasi (melebihi hidup pokok) akan meningkatkan tingkat konsumsi protein karena ternak mempunyai kesempatan untuk makan lebih banyak (Haryanto dan Djajanegara, 1993).

Peningkatan konsumsi protein juga dipengaruhi oleh kandungan protein dalam pakan yaitu semakin tinggi kandungan protein semakin banyak pula protein yang terkonsumsi (Boorman, 1980). Tingginya protein terkonsumsi diharapkan dapat meningkatkan jumlah protein yang teretensi dalam tubuh ternak dan dimanfaatkan ternak untuk memenuhi hidup pokok dan berproduksi.Pemanfaatan protein selain terkait dengan level pemberian pakan juga terkait dengan bobot badan ternak. Ternak yang berbobot badan rendah dan masuk masa pertumbuhan membutuhkan protein lebih tinggi dibandingkan ternak dewasa yang telah masuk masa penggemukan (Orskov, 1992).

Fungsi protein dalam tubuh adalah membangun dan menjaga atau memelihara protein jaringan dan organ tubuh, menyediakan asam-asam amino makanan, menyediakan enegi dalam tubuh, menyediakan sumber lemak badan,menyediakan sumber gula darah, sumber glikogen darah, sumber enzyme tubuh, sumber beberapa hormon dalam tubuh, menyediakan bangunan dasar untuk setidak-tidaknya satu vitamin B komplek, menyediakan komponen tertentu dari DNA, RNA dan ATP (Tillman et al., 1991). 


\section{KESIMPULAN}

Pemberian ransum yang mengandung pelepah daun kelapa sawit dengan perlakuan kombinasi perlakuan fisik, biologi dan kimia meningkatkan kecernaan serat kasar dan kecernaan protein kasar pada domba.

\section{DAFTAR PUSTAKA}

Boorman, D. H., D. E. Hogue, V. K. Vishell, R. H. D. Dalrymple and C. A. Ricks. 1980. Effects of cimaterol and fishmeal on performance, carcass characteristics and skeletal muscle growth in lambs. J. Anim. Sci. $62: 370$.

Despal, disitasi oleh H. Suprapto, FM 2000. Kecernaan Serat Kasar Dan Lemak Kasar Complete Feed Limbah Rami Dengan Sumber Protein Berbeda Pada Kambing Pernakan Etawa Lepas Sapih (Feed Composition). Universitas Jendral Soedirman, Purwokerto

Haryanto, B. dan Andi Djajanegara, 1993. Pemenuhan Kebutuhan zat-zat pakan ruminansia kecil, dala produksi kambing dan domba di Indonesia, editor : Monica W., dkk, Solo : Sebelas Maret University Press.

Kartadisastra, H.R., 1997. Penyediaan dan Pengelolaan Pakan Ternak Ruminansia. Kanisius. Yogyakarta.

Muchtadi, D., S. D. Nurhaeni, dan M. Astawan. 1992. Bahan Kuliah. Enzim Dalam Industri Pangan, Departemen Pendidikan dan Kebudayaan, Dirjen Dikti. PAU Pangan dan Gizi.IPB. Bogor.

Orskov, E. R. 1992. Protein Nutrition in Ruminant. Academic Press, Harcout Brace Jovanovich Publisher, London

Sarwono P. 1996. Beternak Domba, Yayasan Bina Pustaka Sarwono Prawiro Hardjo. Jakarta

Siregar, Z., 2009. Suplementasi Block Multinutrisi Berbasis Hijauan Lapangan Terhadap Kecernaan in vivo pada Domba Jantan. Departemen Peternakan, Fakultas Pertanian, Universitas Sumatera Utara, Medan

Thomaszewska, M. W., I. M. Mastika., A. Djajanegara., S. Gardiner dan T. R. Wiradarya. 1993. Produksi Kambing dan Domba di Indonesia. Sebelas Maret, Surabaya. 
Tillman A. D., H. Hartadi, S. Reksohadiprojo, S. Prawirokusumo dan S. Lepdosoekojo. 1991. Ilmu Makanan Ternak Dasar. UGM-Press, Yogyakarta.

Van Soest, P. J. 1994. Valuntaru Intake in Relation to Chemical Compocition and Digestibility. J. Anim. Sci. 24 : 834 